\title{
PERSEPSI CALON WAJIB PAJAK ATAS TINDAK PENGGELAPAN PAJAK
}

\author{
Miranda Lamia ${ }^{1}$, Jenny Morasa ${ }^{2}$, Sintje Rondonuwu ${ }^{3}$ \\ 1,2,3 Jurusan Akuntansi, Fakultas Ekonomi dan Bisnis, Universitas Sam Ratulangi, Jl. Kampus Bahu, Manado, \\ 95115, Indonesia
}

E-mail : mirandajuliaaa@yahoo.com

\begin{abstract}
Tax Evasion is a major problem in the Indonesian economics which related to state tax income. To know the perception of tax evasion done by taxpayers, we can observe it from the perception of future taxpayers like college student. The method used in this research is descriptive method, in the way of analyzing each data and then presented based on narrative data groups for conclusion to be mades. The result of this research is prospective student taxpayers of Politeknik Negeri Manado see that tax evasion from perceptions of tax system, feeling of justice and discrimination as an unreasonable act against the law.
\end{abstract}

Keywords : Perception, Student, Prospective Student Future Taxpayers, Tax, Tax Evasion.

\section{PENDAHULUAN}

Saat ini Indonesia memprioritaskan sektor pajak sebagai sumber pendapatan terbesar negara dalam APBN. Pajak yang dipungut oleh pemerintah digunakan untuk membiayai pembangunan negara dan untuk membayar hutang negara beserta bunganya yang diharapkan dengan langkah - langkah tersebut kesejahteraan masyarakat dapat tercapai. Sektor pajak yang merupakan sumber pendapatan utama negara ternyata belum mencapai target yang diinginkan. Hal ini dapat dilihat dari Laporan Tahunan Direktorat Jendral Pajak (Direktorat Jendral Pajak Kementerian Keuangan, 2017) yang diolah pada Tabel 1.

Tabel 1. Target dan Realisasi Penerimaan Pajak Indonesia Laporan Tahunan Direktorat Jendral Pajak dari Tahun 2012 - 2016

\begin{tabular}{crrr}
\hline Tahun & Target $(\mathbf{R p )}$ & Realisasi $\mathbf{( R p )}$ & \multicolumn{1}{c}{ Persentase $\mathbf{( \% )}$} \\
\hline 2012 & 885,01 Triliun & 835,85 Triliun & 94,44 \\
2013 & 1.139,32 Triliun & $1.072,10$ Triliun & 93,40 \\
2014 & 1.072,38 Triliun & 985,13 Triliun & 91,50 \\
2015 & $1.294,258$ Triliun & $1.060,86$ Triliun & 81,97 \\
2016 & $1.355,203$ Triliun & $1.105,97$ Triliun & 81,61 \\
\hline
\end{tabular}

Sumber: Laporan Tahunan 2012 - 2016 Direktorat Jendral Pajak

Ketergantungan pemerintah terhadap penerimaan pajak ternyata belum sepenuhnya memenuhi target yang telah ditetapkan. Hal ini terlihat dari persentase realisasi penerimaan pajak tahunan negara yang nilainya masih cukup jauh dari target penerimaan, begitu pun untuk tahun 2017 yang realisasinya hanya mencapai 91\% dari target yang telah ditentukan yaitu Rp. 1.730,3 Triliun. Sementara sumber pendapatan bukan dari pajak sebesar Rp. 250 Triliun dan hibah sebesar Rp. 1,4 Triliun.

Lebih dari $80 \%$ pendapatan negara berasal dari penerimaan pajak, maka dari itu pajak menjadi aspek penting dalam pembangunan, namun dengan tidak pernahnya terpenuhi target penerimaan pajak negara merupakan indikator adanya faktor - faktor yang menghambat dalam realisasi penerimaan pajak negara salah satunya karena adanya indikasi penghindaran dan penggelapan pajak oleh wajib pajak orang pribadi maupun badan (Suwiknyo : 2018). 
Penghindaran pajak mengarah pada usaha mengurangi pajak secara legal dengan diikuti pengungkapan informasi penuh kepada otoritas pajak, sedangkan penggelapan pajak mengarah pada usaha mengurangi pajak secara ilegal dengan melibatkan penipuan, penyembunyian, atau menghilangkan catatan bahkan menghilangkan beban pajaknya (Fisher, 2014). Terdapat banyak bentuk dan modus penggelapan pajak yang diatur dalam Undang Undang No. 16 Tahun 2009 diantaranya ialah menggelembungkan biaya, menyembunyikan omset modus, memalsukan faktur pajak, rekayasa bukti potong, dan mengkapitalisasi kerugian.

Pemerintah berdasarkan surat edaran yang dikeluarkan oleh Direktur Jenderal Pajak Nomor SE 98/PJ/2011 Tentang Pedoman Penyusunan Rencana Kerja Dan Laporan Kegiatan Penyuluhan Perpajakan Unit Vertikal Di Lingkungan Direktorat Jenderal Pajak, mulai memfokuskan sosialisasi kepada mahasiswa, yang dimana hal ini tentunya tidak terlepas dari peranan mahasiswa sebagai agent of change dalam permasalahan penggelapan pajak. Mahasiswa dituntut untuk menjadi agen perubahan dalam lingkungan, mahasiswa harus menjadi garda terdepan dalam memberikan kontribusi yang konkret dalam setiap kebijakan pemerintah yaitu dengan memberikan informasi perpajakan yang benar kepada masyarakat, agar tidak menjadi free rider dan mengubah pola pikir masyarakat mengenai pajak. Adapun rumusan masalah dalam penelitian ini ialah :

1. Bagaimana persepsi calon wajib pajak mahasiswa atas tindak penggelapan pajak dari sudut pandang sistem pajak yang berlaku di Indonesia saat ini?

2. Bagaimana persepsi calon wajib pajak mahasiswa atas tindak penggelapan pajak dari sudut pandang keadilan dari sisi wajib pajak?

3. Bagaimana persepsi calon wajib pajak mahasiswa atas tindak penggelapan pajak dari sudut pandang diskriminasi?

\section{TINJAUAN PUSTAKA}

Akuntansi. Konsep dasar akuntansi dikatakan sebagai suatu konsep yang berlaku umum mengenai suatu asumsi, anggapan, pandangan maupun pendapat dalam menyajikan informasi keuangan kepada pihak yang berkepentingan (Utiarahman, Tinangon dan Afandi, $2017: 433)$.

Konsep perpajakan. Menurut Pudihang, Morasa dan Gamaliel (2017 : 273) akuntansi perpajakan digambarkan sebagai proses pencatatan, penggolongan, dan pengikhtisaran transaksi keuangan yang berkaitan dengan kewajiban perpajakan yang akan menghasilkan laporan keuangan fiskal sesuai dengan ketentuan dan peraturan perpajakan sebagai dasar pembuatan surat pemberitahuan tahunan. Menurut Djohar, Karamoy, dan Warongan (2017 : 384), pajak pada umumnya ialah suatu perwujudan tanggung jawab kenegaraan masyarakat yang disetorkan kepada pemerintah untuk pembiayaan dan pembangunan negara. Kontribusi dari rakyat tersebut kemudian diolah oleh pemerintah untuk menyediakan barang dan jasa publik yang merupakan kebutuhan masyarakat.

Persepsi. Menurut Arifin, Fuady dan Kuswarno (2017 : 92), persepsi dipengaruhi oleh faktor internal dan faktor eksternal. Faktor internal ialah faktor yang muncul dari dalam diri seseorang seperti proses belajar, perhatian, karakter individu, keinginan, perasaan, kejiwaan, keadaan fisik, minat, motivasi dan kebutuhan. Yang dimaksudkan dengan faktor eksternal ialah informasi yang diperoleh, pengetahuan, kebutuhan, intensitas, pengulangan gerak, latar belakang keluarga, hal - hal baru dan ketidakasingan objek. Dari faktor - faktor yang ada maka Walgito (Arifin dkk, 2017 : 91) menggambar proses pembentukan persepsi sebagai berikut : 


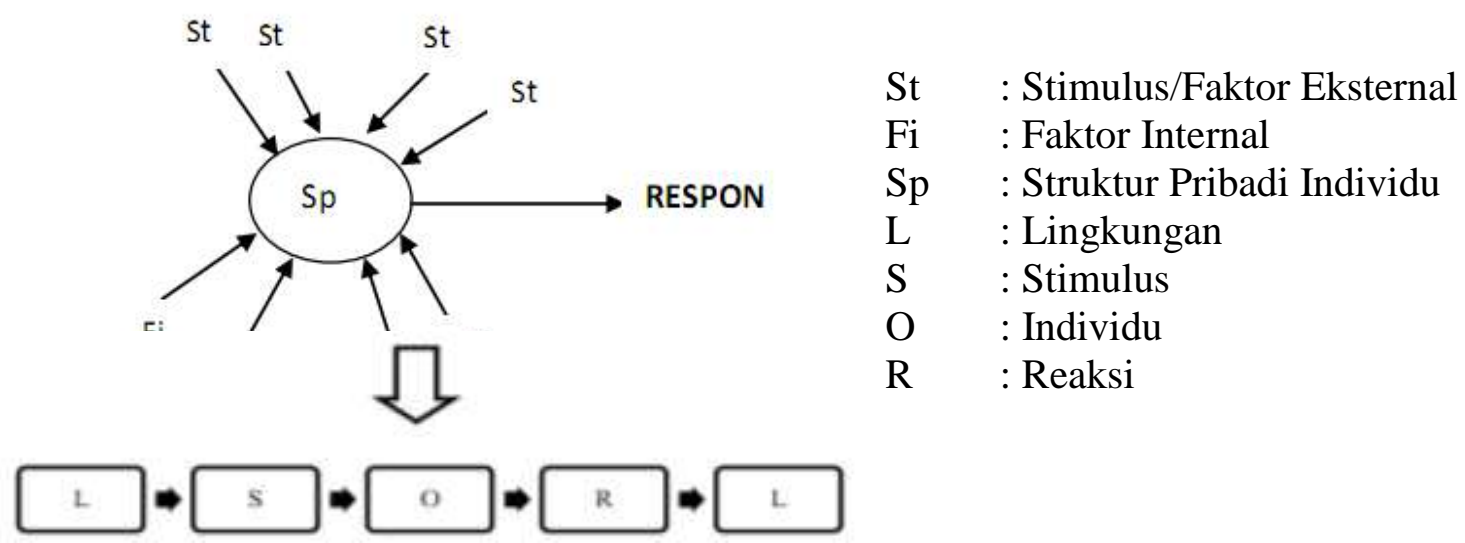

Gambar 1. Proses Pembentukan Persepsi

Calon wajib pajak. Calon wajib pajak diartikan sebagai orang pribadi atau badan yang akan menjadi pembayar, pemotong, dan pemungut pajak, yang mempunyai kewajiban dan hak perpajakan sesuai dengan ketentuan yang berlaku.

Penggelapan pajak. Menurut Abrahams dan Kristanto (2016: 51) penggelapan pajak adalah usaha yang dilakukan oleh wajib pajak dengan mengatur sebuah peristiwa untuk meminimalkan atau bahkan menghilangkan beban pajak, mengurangi atau sama sekali menghapus dengan memperhatikan ada atau tidaknya akibat yang ditimbulkan berdasarkan ketentuan dan perundang - undangan perpajakan yang berlaku. Secara sederhana, penggelapan pajak atau tax evasion adalah tindakan yang dilakukan oleh wajib pajak untuk mengurangi jumlah pajak sebagaimana yang terutang atau sama sekali tidak membayarkan pajaknya melalui cara - cara manipulasi yang ilegal. Menurut Abrahams dan Kristanto (2016 : 54) kecenderungan terjadinya penggelapan pajak disebabkan oleh beberapa hal antara lain pajak yang dibayarakan dirasa terlalu tinggi, mudahnya melakukan penyuapan, peluang terungkap kecurangan dan ancaman hukum yang dinilai masih rendah bagi pelaku penggelapan pajak.

Persepsi calon wajib pajak dan penggelapan pajak. Persepsi atas penggelapan pajak seorang calon wajib pajak dapat dipengaruhi oleh faktor - faktor diluar struktur pribadi individu (faktor eksternal) yaitu sudut pandang sistem pajak, keadilan dan diskriminasi (Reskino, 2014 : 54). Persepsi terbentuk dari seberapa besar pemahaman calon wajib pajak terhadap hak dan kewajibannya sebagai wajib pajak nantinya. Selain itu, persepsi calon wajib pajak dapat terbentuk dari seberapa besar pengetahuannya mengenai peraturan pajak yang berlaku serta sanksi - sanksi pajak yang akan diterima jika terjadi pelanggaran. Kunci dalam memahami persepsi adalah pada prinsip dimana persepsi merupakan penafsiran yang unik terhadap suatu situasi dan bukan suatu pencatatan kebenaran terhadap situasi. Hal itu dapat digambarkan melalui bagan berikut : 


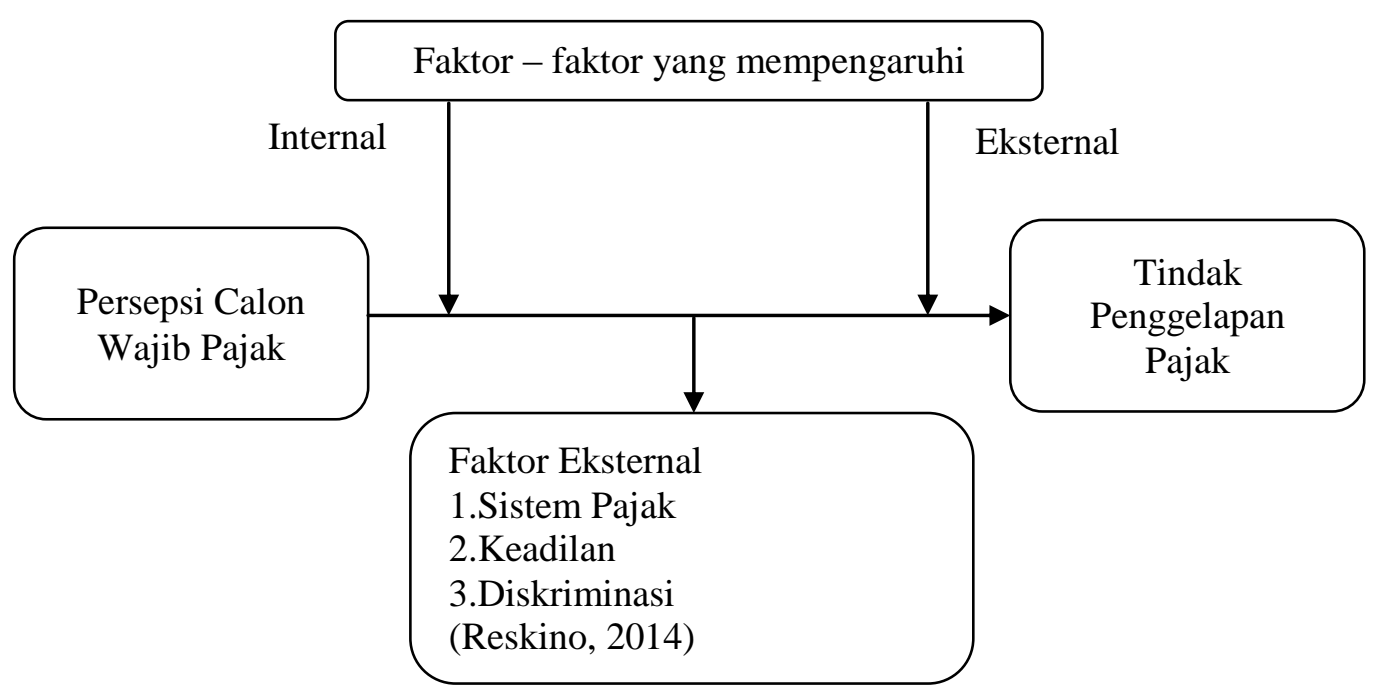

\section{Gambar 2. Persepsi Calon Wajib Pajak Terhadap Penggelapan Pajak}

Penelitian terdahulu. Kurniawan A dan Nazier M (2014) dengan judul Analisis Sensitivitas Etika Wajib Pajak terhadap Tax Evasion. Tujuan penelitian ialah untuk melihat pengaruh persepsi terhadap perilaku dalam melakukan tax evasion dilihat dari perspektif usia, gender, pendidikan, pekerjaan dan status pernikahan. Metode penelitian yang digunakan ialah kualitatif dan kuantitatif. Hasil penelitian dilihat dari segi kode etik oleh wajib pajak pribadi, maka tax evasion adalah etis berdasarkan alasan - alasan tertentu. Abrahams dan Kristanto (2016) dengan judul Persepsi Calon Wajib Pajak dan Wajib Pajak Terhadap Etika Penggelapan Pajak Di Salatiga. Tujuan penelitian ini ialah untuk mengeksplorasi persepsi calon wajib pajak dan wajib pajak terhadap perilaku penggelapan pajak dari sudut pandang sistem perpajakan, keadilan pajak dan diskriminasi perpajakan. Metode penelitian ialah survei pada responden. Hasil penelitiannya ialah rata - rata responden tidak setuju bahwa tindak penggelapan pajak adalah hal yang etis, walaupun sistem pajak tidak baik, terdapat ketidakadilan dan diskriminasi dalam dunia perpajakan.

\section{METODE PENELITIAN}

Jenis penelitian. Jenis penelitian yang digunakan adalah penelitian deskriptif kualitatif. Persepsi dinilai secara dalam dengan berlandaskan paradigma interpretif dan berdasarkan sudut pandang subjektif tentang keadaan sosial yang ada, serta mengungkapkan kesadaran dari calon wajib pajak mengenai keterlibatannya dalam tindak antisipatif penggelapan pajak (Maryati dan Tarzimi, $2015: 6$ ).

Tempat dan waktu penelitian. Penelitian ini dilaksanakan di Politeknik Negeri Manado, Kota Manado, Provinsi Sulawesi Utara. Waktu penelitian dilaksanakan pada bulan Juni - Juli 2018.

\section{Jenis, sumber dan metode penelitian}

Jenis Data. Penelitian ini menggunakan data kualitatif yang bersifat deskriptif, yaitu berupa hasil wawancara pada calon wajib pajak mahasiswa Politeknik Negeri Manado atas tindak penggelapan pajak.

Sumber Data. Data yang digunakan dalam penelitian ini adalah data primer yaitu data yang diperoleh dengan cara melakukan penelitian langsung ke lapangan dengan melakukan wawancara terkait pemahaman dan pandangan calon wajib pajak mahasiswa mengenai 
penggelapan pajak. Calon wajib pajak yang dimaksudkan dalam penelitian ini ialah mahasiswa Politeknik Negeri Manado jurusan akuntansi angkatan 2014 - 2015 yang telah mengambil mata kuliah terkait perpajakan.

Metode pengumpulan data. Penelitian ini menggunakan teknik pengumpulan data melalui wawancara kepada pihak informan yang terlibat dalam penelitian ini guna memenuhi keperluan peneliti tentang kejelasan masalah penelitian dan dokumentasi hasil pengumpulan data dan telaah pustaka yang dianggap relevan dengan permasalahan yang akan diteliti.

Metode dan proses analisis. Metode Analisis data yang digunakan dalam penelitian ini adalah metode analisis kualitatif deskriptif, yaitu peneliti mendeskripsikan hasil temuannya yang berasal dari data - data yang terkumpul melalui proses wawancara pada objek penelitian yang kemudian akan dikaitkan dengan penggelapan pajak secara teori yang selama ini berkembang dikalangan akademik. Prosedur analisis data dalam penelitian ini menggunakan teknik analisis interaktif Miles dan Huberman Punch (Agustin dan khuzaini, 2017 : 8), yang mengemukakan bahwa teknik ini terdiri dari tiga komponen yaitu reduksi data, penyajian data lalu penarikan kesimpulan.

\section{HASIL PENELITIAN DAN PEMBAHASAN \\ 4.1. Hasil Penelitian}

Semua responden telah mengambil mata kuliah menyangkut perpajakan dengan delapan orang informan memiliki mata kuliah paling banyak yaitu tiga mata kuliah. Rata rata responden memiliki karya ilmiah mengenai perpajakan yaitu sebanyak sembilan orang, ada yang terlibat dalam kegiatan yang berhubungan dengan perpajakan sebanyak dua orang dan sisanya yaitu satu orang tidak ada atau terlibat. Hal ini menunjukkan bahwa rata - rata mahasiswa di Politeknik Negeri Manado memiliki pemahaman perpajakan yang berasal dari proses perkuliahan meskipun seluruh responden memang berasal dari jurusan akuntansi yang ada hanya perbedaan program strata. Berdasarkan pemahaman tersebut lebih dari setengah jumlah responden dapat mengaplikasikannya dalam bentuk karya ilmiah yang berarti mereka peka terhadap dunia perpajakan yang ada di masyarakat dan juga ada yang terlibat langsung dalam program perpajakan yang dilaksanakan sebagai tindakan nyata kepedulian mereka atas kondisi perpajakan yang ada di masyarakat. Seluruh responden mengetahui hak dan kewajiban wajib pajak serta peraturan dan ketentuan yang berlaku meskipun berstatus masih sebagai calon wajib pajak sehingga mereka berpotensi menjadi wajib pajak yang taat akan membayar pajak.

Sebagian besar dari responden mengetahui tata cara perhitungan pajak dan tarif yang berlaku, mayoritas dari mereka telah merasa tarif tersebut sesuai dan ada yang merasa tarif yang berlaku masih terlalu rendah. Ada juga yang belum terlalu memahami tentang perhitungan menganggap tarif sudah sesuai dan ada yang menganggap terlalu tinggi. Seluruh responden merespon positif sistem pajak yang telah dimodernisasi dan menanggap bahwa hal tersebut ditambah dengan aparatur perpajakan yang dapat dipercaya merupakan faktor faktor pendorong masyarakat untuk membayar pajak. Manfaat dari pembayaran pajak itu sendiri dirasakan oleh seluruh responden yang diakui secara langsung ataupun tidak dalam bentuk fasilitas dan infrastruktur yang ada sehingga ketentuan yang ada dirasakan adil karena hal tersebut bisa dinikmati oleh semua elemen masyarakat. Berdasarkan hal tersebut hampir seluruh kecuali satu responden merasakan bahwa sistem pajak yang ada tidak seimbang dan ada diskriminasi di dalamnya.

Setengah dari seluruh responden menganggap bahwa realisasi penerimaan pajak yang kurang disebabkan oleh penghindaraan dan/ atau penggelapan pajak, sisanya yaitu tiga responden masih kurangnya pemahaman dari wajib pajak yang tentunya masih berhubungan dan yang lain menganggap bahwa hal tersebut karena kelemahan sistem pajak dan kesalahan 
pemerintah yang merupakan satu kesatuan. Mayoritas dari responden mengetahui apa itu penggelapan pajak dan/ atau contoh dan tata caranya sementara yang lain masih sulit membedakan penghindaran pajak dan penggelapan pajak.

\subsection{Pembahasan}

Persepsi Calon Wajib Pajak Mahasiswa Atas Tindak Penggelapan Pajak Dari Sudut Pandang Sistem Pajak Yang Berlaku Di Indonesia Saat Ini. Sebagian besar dari responden memahami tata cara perhitungan yang ada dan menganggap tarif yang berlaku sudah sesuai dengan keadaan di Indonesia. Ada pula responden yang berpandang berbeda bahwa tarif pajak yang berlaku khususnya dalam pajak penghasilan masih terlalu tinggi dan cenderung berubah - ubah dan ada yang menilai tarif pajak yang berlaku saat ini masih rendah untuk menimbulkan efek jerah. Begitu pula dengan aspek mengenai sistem pajak yang moderen dan aparatur perpajakan, semua responden sepaham bahwa kedua hal tersebut menjadi faktor pendorong masyarakat membayar pajak. Hal ini sesuai dengan teori yang dikemukakan oleh Abrahams dan Kristanto (2016 : 54) dimana tarif yang dianggap tinggi menjadi pendorong masyarakat melakukan penggelapan pajak.

Persepsi Calon Wajib Pajak Mahasiswa Atas Tindak Penggelapan Pajak Dari Sudut Pandang Keadilan Dari Sisi Wajib Pajak. Untuk sudut pandang keadilan, aspek aspeknya adalah pemanfaatan dana pajak dan prinsip kemampuan masyarakat dalam membayar pajak. Semua responden menjawab bahwa mereka baik langsung maupun tidak merasakan manfaat pembayaran pajak melalui fasilitas dan infrastukur yang dibangun oleh pemerintah. Rata - rata responden paham bahwa hal pembangunan yang terjadi dilingkungan mereka dan diseluruh penjuru Indonesia merupakan kontribusi dari dana pajak yang dibayarkan. Tetapi ada pula responden masih ragu apakah pembangunan tersebut berhubungan dengan pembayaran pajak. Mengenai kemampuan masyarakat dalam membayar pajak, semua responden setuju bahwa kebijakan perpajakan yang ada telah mempertimbangkan kemampuan sosial dan ekonomi masyarakat karena seperti yang dipaparkan oleh salah satu responden, ada yang bersifat progresif seperti pajak penghasilan ada yang merata untuk semua seperti pajak pertambahan nilai.

Persepsi Calon Wajib Pajak Mahasiswa Atas Tindak Penggelapan Pajak Dari Sudut Pandang Diskriminasi. Diskriminasi merupakan sudut pandang atau persepsi ketiga yang dibahas dalam penelitian ini. Aspek yang termasuk dalam diskrimasi adalah perlakuan perbedaan pelayanan atas dasar suku, ras dan agama, kelas sosial maupun kebijakan yang dapat menguntungkan pihak tertentu. Berdasarkan hasil penelitian, hampir seluruh responden yang berarti calon wajib pajak mahasiswa Politeknik Negeri Manado berpendapat bahwa tidak ada perlakuan yang tidak seimbang dan/ atau kebijakan - kebijakan yang menguntungkan pihak tertentu. Namun, ada satu responden yang merasa ada kebijakan yang menguntukan pihak tertentu yaitu tax amnesty. Responden tersebut merasa bahwa kebijakan tax amnesty yang dikeluarkan oleh pemerintah untuk meningkatkan jumlah pajak, tetapi justru itu menjadi keringanan buat oknum - oknum tertentu. Kurangnya penerimaan pajak ditanggapi beragam oleh responden, setengah dari seluruh responden berpandangan bahwa hal tersebut berkaitan dengan wajib pajak untuk menghindar bahkan melakukan penggelapan, tiga responden menganggap hal tersebut hanya karena masyarakat yang kurang memiliki kesadaran membayar pajak, dan dua responden menganggap hal tersebut adalah kelalaian dari petugas pajak atau pun pemerintah. Tindak penggelapan pajak berdasarkan persepsi dari mahasiswa Politeknik Negeri Manado sebagai calon wajib pajak sudah dipahami sebagai tindakan tidak wajar bahkan ada responden yang berkesimpulan bahwa penggelapan pajak adalah tindak kriminalitas. Akan tetapi masih ada dua responden yang belum dapat membedakan antara penghindaran pajak dan penggelapan pajak. hal ini merupakan evaluasi terhadap pemahaman mengenai tindak penggelapan pajak dikalangan calon wajib pajak. 


\section{KESIMPULAN DAN SARAN}

\subsection{Kesimpulan} ini adalah :

Berdasarkan hasil dan pembahasan pada bab sebelumnya, kesimpulan dari penelitian

1. Berdasarkan penilaian yang baik terhadap sistem pajak maka persepsi calon wajib pajak mahasiswa di Politeknik Negeri Manado atas tindak penggelapan pajak adalah tidak wajar jika dilakukan oleh wajib pajak.

2. Dengan terwujudnya rasa keadilan dalam perpajakan maka persepsi calon wajib pajak mahasiswa di Politeknik Negeri Manado atas tindak penggelapan pajak adalah tidak wajar jika dilakukan oleh wajib pajak.

3. Dengan tidak ditemukannnya diskriminasi dalam perpajakan maka persepsi calon wajib pajak mahasiswa di Politeknik Negeri Manado atas tindak penggelapan pajak adalah tidak wajar jika dilakukan oleh wajib pajak.

\subsection{Saran}

Berdasarkan kesimpulan dari penelitian ini, penulis menyarankan bahwa :

1. Terus diadakan sosialisasi akan perpajakan dalam wujud apapun baik untuk masyarakat umum atau khusus untuk mahasiswa. Mahasiswa yang merupakan agent of change tentunya diharapkan oleh pemerintah dapat membantu agenda pembangunan negara salah satunya dengan lebih berkontrbusi dalam sosialisasi menyangkut pajak baik dalam bentuk tulisan ataupun kegiatan.

2. Pemerintah khususnya Direktorat Jendral Pajak beserta stakeholder yang terkait melaksanakan tindakan komprehensif untuk memberantas penggelapan pajak dimulai dari pencegahan, penanganan dan pemulihan tidak hanya untuk pelaku ataupun masyarakat tapi juga dari dalam institusi - intitusi terkait untuk menunjukkan transparansi dan akuntabilitas dalam mengelola pajak untuk pembangunan negara.

\section{DAFTAR PUSTAKA}

Abrahams N. B. dan Kristanto A.B. 2016. Persepsi Calon Wajib Pajak dan Wajib Pajak Terhadap Etika Penggelapan Pajak Di Salatiga. Berkala Akuntansi dan Keuangan Indonesia 1(1): $50-70$.

Agustin A. dan Khuzaini. 2017. Persepsi Masyarakat Terhadap Penggunaan Transportasi Online (Go-Jek) Di Surabaya. Jurnal Ilmu dan Riset Manajemen 6(9).

Arifin H. S., Fuady I., dan Kuswarno E. 2017 Analisis Faktor Yang Mempengaruhi Persepsi Mahasiswa Untirta Terhadap Keberadaan PERDA Syariah di

Kota Serang. Jurnal Penelitian Komunikasi dan Opini Publik 21(1): 88-101.

Direktorat Jendral Pajak Kementerian Keuangan. 2017. Laporan Tahunan DJP. http://www.pajak.go.id/content/laporan-tahunan-djp. 19 Januari 2017 (15:47).

Djohar A.A, Karamoy H., dan Warongan J. D. 2017. Analisis Pemotongan PPh Pasal 4

Ayat 2 Terhadap Lelang Pada Kantor Pelayanan Kekayaan Negara Dan Lelang Manado. Jurnal Riset Akuntansi Going Concern 12(2):383-390.

Fisher dan Jasmine M. 2014. Fairer Shores: Tax Heavens, Tax Avoidance, and Corporate Social Responsibility. Boston University Law 94: 337-365.

Kurniawan A., dan Nazier D.M. 2014. Analisis Sensitivitas Etika Wajib Pajak Terhadap Tax Evasion. Dimensia 11(1): 1-30.

Maryati dan Tarmizi M.I. 2015. Pemahaman dan Persepsi Etis Akuntan Pajak Tentang Tax Avoidance Dan Tax Evasion. Simposium Nasional Akuntansi 18 Medan. 28 Oktober: 161. 
Pudihang S., Morasa J., dan Gamaliel H. 2017. Mekanisme Pemungutan Pajak Atas Pemindahan Hak Pada Jual Beli Tanah Dan Bangunan Di Kabupaten Kepulauan Siau Tagulandang Biaro (Sitaro). Jurnal Riset Akuntansi Going Concern 12(1) : 272283.

Reskino, Rini dan Novitasari. 2014. Persepsi Mahasiswa Akuntansi Mengenai Penggelapan Pajak. Jurnal InFestasi 10(1): 49 - 63.

Surat Edaran Jenderal Pajak Nomor SE 98/PJ/2011 Tahun 2011 Tentang Pedoman Penyusunan Rencana Kerja Dan Laporan Kegiatan Penyuluhan Perpajakan Unit Vertikal Di Lingkungan Direktorat Jenderal Pajak Kementerian Keuangan Republik Indonesia Direktorat Jenderal Pajak. Jakarta.

Suwiknyo E. 2018. TREN SHORTFALL : Saatnya Evaluasi Pajak. http://kalimantan.bisnis.com/read/20180102/433/722503/tren-shortfall-saatnyaevaluasi-pajak. Bisnis.com. 02 Januari 2018 (02:00).

Utiarahman N. P., Tinangon J. J., dan Afandi D. 2017. Analisis Perhitungan Dan Pelaporan Pajak Penghasilan (PPh) Di P.T Bank SULUTGO. Jurnal Riset Akuntansi Going Concern 12(2) : $432-440$. 